\title{
Analisis Pengembangan Wirausaha Lokal di Propinsi Riau
}

\author{
Eka Armas Pailis ${ }^{1}$, Ahmad Fauzan Fathoni ${ }^{2}$, Fuad Ashrofillah $^{3}$ \\ Fakultas Ekonomi Universitas Riau Pekanbaru, 28293 \\ Email: pailis.ur@gmail.com
}

\begin{abstract}
The development of an entrepreneurial-based local economic development outlined for 6 districts / cities that we studied. Determination of the commodity is determined by predetermined criteria, and the determination of these criteria is based on the objectives to be achieved in the development of local entrepreneurship. To obtain uniformity and consistency in the process of establishing a commodity, then each of the criteria used in all districts / cities are the same. Through the analysis using the formula LQ with survey data in the field is known that one of the characteristics of entrepreneurship is to act on business opportunities, business opportunities can be obtained from looking at and analyzing the following three potentials, namely: availability of natural resources, availability of human resources and Market Potential.
\end{abstract}

Keywords: Local Entrepreneur, Location quation

Program penanggulangan kemiskinan yang dilakukan oleh pemerintah lebih bercorak "karitatif" atau memberikan kasih sayang kepada warga miskin. Jadi bukan sebagai upaya untuk mengentaskan kemiskinan melalui kebijakan yang strategik dan terukur. Mestinya yang dibutuhkan adalah kebijakan penanggulangan kemiskinan dan bukannya program kemiskinan. Program kemiskinan yang dimaksud adalah program yang digulirkan secara instan untuk mengurangi kemiskinan sesaat. Sedangkan program penanggulangan kemiskinan lebih bercorak jangka menengah sesuai dengan sasaran untuk mengentaskan kemiskinan secara sistematik dan menyeluruh.

Kebijakan tersebut tentu terkait dengan menempatkan kementerian sebagai leading sektor, penempatan anggaran yang yang bercorak menyatu dan penyeluruh dan ditujukan sesuai dengan sasaran pengentasan kemiskinan. Selama ini terkesan hanya sebagai program lipstick, yang kelihatan merah akan tetapi tidak dirasakan dampaknya secara signifikan. Misalnya, program Inpres Desa Tertinggal (IDT), Bantuan Langsung Tunai (BLT), Pembagian Beras untuk Kaum Miskin (Raskin), Program Nasional Pemberdayaan Masyarakat (PNPM) dan lainnya.
Disebabkan oleh banyaknya
program kemiskinan tersebut, maka
anggaran untuk kemiskinan juga terus
meningkat dari tahun ke tahun. Pada tahun
2004, jumlah anggaran untuk pengentasan
kemiskinan sebesar Rp. 16,7 triliun, tahun
2005 sebesar Rp. 23 triliun, tahun 2006
sebanyak Rp. 42 triliun, tahun 2007
menjadi Rp. 51 triliun, tahun 2008 sebesar
Rp. 63 triliun, tahun 2009 sebesar Rp. 66
triliun dan tahun 2010 sebanyak Rp. 94
triliun. (Kompas, 10/03/2011).
Kenaikan anggaran dari tahun ke tahun, sesungguhnya harus berkorelasi dengan pengurangan angka kemiskinan yang signifikan. Sayangnya bahwa angka kemiskinan tersebut tidak berkurang secara memadai. Misalnya pada tahun 2004, angka kemiskinan sebesar 16,7 persen, lalu turun menjadi 16 peresen tahun 2005. Lalu naik lagi sebesar 17,8 persen pada tahun 2006 , lalu turun menjadi 16,6 persen tahun 2007 , kemudian turun lagi menjadi 15,4 persen tahun 2008, dan kemudian turun lagi menjadi 14,2 persen tahun 2009 dan turun menjadi 13,3 persen tahun 2010. (Kompas, 10/03/2011).

Penurunan angka kemiskinan ini tampaknya tidak berbanding lurus dengan kenaikan anggaran pengentasan kemiskinan dari tahun ke tahun. Semestinya dengan 
semakin tingginya tingkat anggaran yang disediakan untuk pengentasan kemiskinan akan berdampak pada penurunan angka kemiskinan secara signifikan. Akan tetapi kenyataan empirisnya justru terjadi angka yang fluktuatif tentang hal ini. Memang harus diakui bahwa terdapat penurunan angka kemiskinan dari tahun ke tahun, terkecuali tahun 2006. Akan tetapi dibandingkan dengan peningkatan anggaran anti kemiskinan, maka harus ada evaluasi yang menyeluruh tentang program pengentasan kemiskinan tersebut. Program raskin, BLT dan bahkan PNPM juga memang akan baik jika dikaji ulang sebagai resep pengentasan kemiskinan.

Sebagaimana program pengentasan kemiskinan di Provinsi Riau, maka memang juga harus diklasifikasi melalui by name and by address tentang kategorisasi kaum miskin itu dan kemudian memberikan layanan yang sesuai dengan kategori yang sudah ada. Jadi program pengentasan kemiskinan tidak bisa hanya dilakukan sebagai program karitatif akan tetapi harus dilakukan dengan design yang sangat baik dan memadai, sehingga program pengentasan kemiskinan akan bisa sampai kepada sasarannya sesuai dengan kenyataan empirisnya.

Kewirausahaan berasal dari kata wira dan usaha. Wira, berarti pejuang, pahlawan, manusia unggul, teladan, berbudi luhur, gagah berani dan berwatak agung. Usaha, berarti perbuatan amal, bekerja, berbuat sesuatu. Jadi wirausaha adalah pejuang atau pahlawan yang berbuat sesuatu. Ini baru dari segi etimologi (asal usul kata). Menurut Kamus Besar Bahasa Indonesia, wirausaha adalah orang yang pandai atau berbakat mengenali produk baru, menentukan cara produksi baru, menyusun operasi untuk mengadakan produk baru, mengatur permodalan operasinya serta memasarkannya. Secara epistimologis kewirausahaan hakikatnya adalah suatu kemampuan dalam berfikir kreatif dan berperilaku inovatif yang dijadikan dasar, sumber daya, tenaga penggerak, tujuan, siasat, kiat dalam menghadapi tantangan hidup. Kewirausahaan yang sering dikenal dengan sebutan entrepreneurship berasal dari Bahasa Perancis yang diterjemahkan secara harfiah adalah perantara, diartikan sebagai sikap dan perilaku mandiri yang mampu memadukan unsur cipta, rasa dan karsa serta karya atau mampu menggabungkan unsur kreativitas, tantangan, kerja keras dan kepuasan untuk mencapai prestasi maksimal.

Dalam lampiran Keputusan Menteri Koperasi dan Pembinaan Pengusahan Kecil Nomor 961/KEP/M/XI/1995, dicantumkan bahwa: (a) Wirausaha adalah orang yang mempunyai semangat, sikap, perilaku dan kemampuan kewirausahaan,

Kewirausahaan adalah semangat, sikap, perilaku dan kemampuan seseorang dalam menangani usaha atau kegiatan yang mengarah pada upaya mencari, menciptakan serta menerapkan cara kerja, teknologi dan produk baru dengan meningkatkan efisiensi dalam rangka memberikan pelayanan yang lebih baik dan atau memperoleh keuntungan yang lebih besar.

Menurut Suryana (2001) dari Thomas W. Zimmerer, kewirausahaan adalah hasil dari suatu disiplin, proses sistematis penerapan kreativitas dan keinovasian dalam memenuhi kebutuhan dan peluang di pasar. Kewirausahaan pada hakikatnya adalah sifat, ciri, dan watak seseorang yang memiliki kemauan dalam mewujudkan gagasan inovatif ke dalam dunia nyata secara kreatif. Kreativitas adalah berfikir sesuatu yang baru, keinovasian adalah bertindak melakukan sesuatu yang baru. Jiwa kewirausahaan ada pada setiap orang yang memiliki perilaku inovatif, kreatif, menyukai perubahan kemajuan dan tantangan. Jadi wirausaha itu mengarah kepada orang yang melakukan usaha/kegiatan sendiri dengan segala kemampuan yang dimilikinya. Sedangkan kewirausahaan menunjuk kepada sikap mental yang dimiliki seorang wirausaha dalam melaksanakan usaha/kegiatan.

Sehingga kewirausahaan unggul merupakan pelopor dan pejuang dalam usaha keluar dari lingkaran kemiskinan

p.ISSN: $2407-800 X \quad$ e.ISSN: 2541-4356 
yang merupakan masalah negara berkembang tak terkecuali di Indonesia dan tentu kantong kemiskinan ada di daerah dan pedesaan, maka program penanggulangan kemiskinan di Provinsi Riau sangat berarti untuk pengurangan angka kemiskinan dengan menumbuh kembangkan kewirausahaan yang unggul sesuai potensi, kompetensi, kearifan lokal yang tersedia di wilayah Provinsi Riau.

Dari banyak kasus yang menggambarkan perilaku para wirausaha sosial, misalnya para penerima Ashoka Fellows, dapat disimpulkan bahwa keenam hal tersebut di atas dapat diadopsi sebagai karakteristik perilaku dan sikap wirausaha sosial. Dengan demikian, pengertian kewirausahaan cenderung menjadi makin luas, tidak terbatas hanya pada wirausaha bisnis. Luasnya cakupan kewirausahaan menggugah kemungkinan untuk membuat tipologi wirausaha Tidak semua wirausaha bisnis sama tingkat kewirausahaannya. Ada yang melakukan tindakan membuat usaha baru sebagai alternatif mengganti jalur sebagai karyawan. Tindakan itu bertujuan mencapai keberhasilan untuk bertahan hidup tanpa berada dalam organisasi yang dimiliki dan/atau dipimpin orang lain. Di lain pihak, terdapat tingkat kompleksitas yang ekstrim dalam berwirausaha, yakni melakukan tindakan kewirausahaan dengan tujuan menghasilkan karya yang dapat mengubah dunia. Misalnya, Steve Job berobsesi menghasilkan komputer yang mudah dipakai oleh banyak orang (personal computer), tidak hanya oleh ahli komputer. Di awal jaman bahasa komputer, penggunaan komputer hanya dikuasai oleh sejumlah ahli yang khusus mempelajari bahasa komputer tersebut. Gagasan Steve Job ditolak oleh perusahaan tempatnya bekerja. Ia memutuskan untuk keluar dan bersama temannya, Steve Wozniak, mendirikan perusahaan baru yang terkenal: Apple Computer.

Adanya pemahaman tentang heterogenitas wirausaha mengakibatkan perluasan bidang penelitian. Misalnya, kewirausahaan yang dikembangkan oleh mereka yang memanfaatkan teknologi $\begin{array}{lccr}\text { tinggi/canggih } & \text { akan } & \text { menjadi bidang } \\ \text { pengembangan } & & \text { "technopreneur". } \\ \text { Munculnya } & \text { cabang } & \text { baru dalam } \\ \text { kewirausahaan } & \text { tidak dapat dihindari. }\end{array}$ Adanya organisasi besar dan mapan yang membutuhkan kelincahan dalam berinovasi dan berubah, telah menumbuhkan jenis wirausaha di dalam perusahaan. Jenis wirausaha di dalam perusahaan disebut "intrapreneur" yang merupakan kependekan "intra corporate entrepreneur". Salah satu bidang kewirausahaan baru yang juga menarik untuk diteliti dan dikembangkan adalah wirausaha sosial, yang dikenal pula dengan sebutan "sociopreneur".

Pembangunan yang dilaksanakan Provinsi Riau mempunyai berbagai tujuan, dan yang merupakan tujuan akhir dari pembangunan adalah untuk meningkatkan kesejahteraan masyarakat, keamanan dan ketentraman. Salah satu dari tujuan pembagunan yang harus dilakukan saat ini agar tercapainya kesejehteraan masyarakat adalah mengentaskan kemiskinan, keterbelakangan, sehingga akhirnya terjadi perubahan pola hidup masyarakat kepada kondisi dan pola hidup yang lebih baik dan berdaya.

Salah satu indikator keberhasilan pembangunan adalah, sejauh mana kemiskinan dapat dikurangi secara nyata dari waktu kewaktu. Provinsi Riau masih dihadapkan pada permasalahan tingginya jumlah rumah tangga miskin. Pada tahun 2008, BPS Provinsi Riau menyatakan bahwa sebesar $15,19 \%$ dari total rumah tangga yang ada di Provinsi Riau tergolong rumah tangga miskin dan sebahagian besar $(78,21 \%)$ berdomisili di pedesaan, dengan pekerjaan utama sebagai petani dan kepemilikan lahan yang sempit. Kondisi kemiskinan ini kontraditif dengan sumberdaya yang dimiliki Provinsi Riau sebagai produsen minyak bumi sebesar 600.000 barrel per hari atau sekitar 50\% dari produksi Indonesia, perkebunan kelapa sawit seluas 1.486.989 hektar, kelapa seluas 639.340 hektar dan karet seluas 644.729 hektar. Pertumbuhan ekonomi selama 5 tahun terakhir berkisar antara $7.5-8,66 \%$ 
dan pendapatan per kapita (harga berlaku) tahun 2007 mencapai Rp 24,31 juta.

Miskin merupakan kemelaratan dan serba kekurangan yang merupakan sebagai akibat dari keterbatasan atau ketiadaan sumberdaya, dengan kata lain miskin berarti keridak berdayaan, kelemahan dan juga kehinaan (Juliantoro,2004). Kondisi miskin yang disebabkan oleh ketiadaan dan keterbatasan segala akses sehingga masyarakat miskin tidak dapat menjalankan kehidupannya dengan baik dan jauh dari kehinaan.

Kemiskinan dapat dilihat dari dua dimensi. Pertama, kemiskinan dapat dilihat sebagai proses yang dinamis, kompleks, dan beragam. Kemiskinan dapat disebabkan oleh rendahnya mutu modal manusia (human capital), pendapatan dan konsumsi yang rendah serta keterbatasan akses terhadap faktor produksi (assets) dan tingkat pengembalian (return) terhadap faktor-faktor produksi tersebut ( tenaga kerja, modal, mutu modal manusia, tanah dan teknologi).

Kedua, kemiskinan juga merupakan akibat dan memberikan kontribusi terhadap ketersisihan (exclution) atau proses marginalisasi dari proses sosial, politik, dan ekonomi (termasuk pasar). Bentuk dari proses marginalisasi ini bisa tercermin dari sisi gender, etnik, ataupun kelas masyarakat.

Karena sifatnya yang dinamis dan multidimensi tersebut, maka pendapat dan definisi kemiskinan sangat beragam dan senantiasa mengalami perubahan seiring dengan bertambahnya pengetahuan mengenai kemiskinan dan faktor-faktor penentunya. Kemiskinan bila ditinjau dari sebab musababnya dapat dibedakkan menjadi kemiskinan strukturan dan kultural(Siahaan, 1993, Anonim, 1996). Kemiskinan struktural terjadi karena kepincangan struktural sistim sosial, sehingga orang tidak dapat menggunakan sumber-sumber pendapatan yang tersedia,atau usaha yang dilakukan untuk memperbaiki nasib selalu terbentur dengan sistim yang berlaku. Kemiskinan kultural merupakan kemiskinan alamiah sifatnya, yaitu penduduk yang sejak lahir sudah berada dalam lingkungan miskinan.
Bappenas menggunakan dasar pemikiran bahwa kemiskinan adalah situasi serba kekurangan yang terjadi bukan dikehendaki si miskin, melainkan tidak dapat dihindari dengan kekuatan sendiri . Kemiskinan antara lain ditandai oleh sikap dan tingkah laku yang menerima keadaan seakan-akan tidak dapat diubah, dan tercermin didalam lemahnya kemauan untuk maju, rendah kualitas sumberdaya manusia, rendahnya produktivitas, terbatasnya modal, rendahnya pendapatan dan terbatasnya kesempatan berpartisipasi dalam pembangunan(Abbdurrahman dan soekartawi, 1996).

Awalnya, definisi kemiskinan hanya didasarkan pada ketidak mampuan ekonomi, dimana seseorang dikatakan miskin jika tingkat pendapatannya lebih rendah dari batas minimum tertentu yang ditetapkan. Kemudian pada awal 1990an, definisi kemiskinan meluas tidak hanya didasarkan pada tingkat pendapatan tapi juga mencakup ketidakmampuan di bidang kesehatan, pendidikan, dan perumahan. Dalam definisi terbaru menurut Bank Dunia (2000), Kemiskinan didefinisikan sebagai suatu kondisi terjadinya kekurangan pada taraf hidup manusia yang bisa berupa fisik atau sosial. Kekurangan fisik meliputi ketidakcukupan dalam kebutuhan dasar materi dan biologis (basic material and biological needs), termasuk kekurangan dalam nutrisi, kesehatan, pendidikan, dan perumahan. Sedangkan ketidakcukupan sosial meliputi hal-hal yang lebih luas, yaitu kerentanan, ketidakberdayaan, dan ketidakmampuan untuk menyampaikan inspirasi.

Selanjutnya menurut Anonymous (2001), lima faktor yang dianggap berkaitan langsung dengan fenomena kemiskinan adalah : (1) Kapabilitas sumberdaya lahan yang rendah, (2) lokasi yang terisolir dan atau terbatasnya sarana dan prasarana fisik, (3) keterbatasan penguasaan modal dan teknologi, (4) Lemahnya kemampuan kelembagaan formal dan informal penunjang pembangunan,(5)masih 
rendahnya akses social masyarakat terhadap peluang-peluang bisnis yang ada.

Myrdal (1980) juga mengemukakan ada 5 ciri kemiskinan meliputi:

1. Mereka hidup dibawah garis kemiskinan. Pada umumnya tidak memiliki faktor produksi sendiri, seperti tanah yang cukup, modal ataupun ketrampilan. Faktor prodduksi yang dimiliki umumnya sedikit, sehingga kemampuan pendapatan menjadi sangat terbatas.

2. Mereka tidak mempunyai kemungkinan untuk memperoleh aset produksi.

3. Tingkat pendidikan umumnya rendah tidak sampai tamat SD, dan waktu mereka umumnya habis tersita untuk mencari nafkah sehingga tidak ada lagi waktu untuk belajar.

4. Banyak diantara mereka yang tidak mempunyai tanah

5. Banyak diantara mereka yang hidup di kota masih berusia muda dan tidak mempunyai ketrampilan.

Maxwell (1999) menandai karakteristik individu dan rumahtangga miskin dari aspek-aspek penting yang terkait secara tidak langsung pada konsep kemiskinan, seperti: (1) kekurangan pendapatan dan kon-sumsi, (2) keterbelakangan derajat martabat manu-sia, (3) ketersingkiran, (4) menyandang derita sakit, (5) ketidakmampuan untuk bekerja atau menunai-kan tugas, (6) memiliki sumber nafkah yang tidak berkelanjutan, dan (7) ketidakmampuan memenuhi kebutuhan dasar dan serba kekurangan diban-dingkan dengan anggota masyarakat secara rata-rata. Jadi, dengan demikian kemiskinan mempunyai dimensi aktual dan potensial.

Kemiskinan menurut ADB (1999) adalah beberapa hak kehidupan pokok manusia yang tak bisa dipenuhi sehingga menyebabkan seseorang atau sebuah rumahtangga jatuh miskin. Disebutkan lebih lanjut oleh ADB adanya faktor: (1) ketidakcukupan akses pendidikan dan kesehatan, (2) kurangnya reasonable reward atau hasil karya yang mereka tunaikan, dan
(3) ketiadaan perlindungan sosial dari berbagai ke-mungkinan external shock dari aspek social-politik kemasyarakatan. Indikatornya adalah tingkat pendi-dikan dasar, status kesehatan, status gizi dan pang-an, ketersediaan dan akses pada air bersih dan sanitasi, tingkat pendapatan, ketersediaan kesempatan kerja serta berusaha, dan tingkat upah

\section{METODE}

Kegiatan ini dilaksanakan di Provinsi Riau, yang dijadikan objek kegiatan adalah potensi kewirausahaan unggulan yang ada di Provinsi Riau berdasarkan klaster. Data dikumpulkan dengan dua pendekatan yakni melalui survey dan wawancara. Metode pengumpulan data dan analisis data yang akan digunakan dalam Kajian ini adalah metode Metode LQ (Location Quitients). Location Quotients (LQ) adalah sebuah indeks yang mengukur overspecialization atau underspecialization dari sektor tertentu dalam suatu daerah.

\section{HASIL}

Pengembangan wirausaha yang berbasis pengembangan ekonomi lokal diuraikan untuk 6 kabupaten/kota yang menjadi lokasi penelitian ini. Penentuan komoditi unggulan ditentukan dengan kriteria yang telah ditetapkan sebelumnya, dan penentuan kriteria tersebut dilandasi oleh tujuan yang ingin dicapai dalam pengembangan wirausaha lokal. Untuk memperoleh keseragaman dan konsistensi dalam proses penetapan komoditi unggulan, maka setiap kriteria yang digunakan pada semua kabupaten/kota adalah sama.

Salah satu dari sifat kewirausahaan adalah bertindak berdasarkan peluang bisnis, peluang bisnis bisa diperoleh dari mencermati dan menganalisa tiga potensi berikut yaitu :

1. Ketersediaan SDA. Bahan baku atau sumber daya alam bisa langsung diperoleh dari alam, dari budi daya atau didatangkan dari daerah lain. Pemilihan dari ketiga alternative 
sumber bahan baku ini adalah sematamata factor efisiensi

2. Ketersediaan SDM. Tenaga kerja terampil dan tidak terampil memiliki potensi untuk maju

3. Potensi Pasar. Potensi pasar atau peluang permintaan komoditas bersumber dari dalam dan luar negeri, kedekatan budaya, selera dan adat istiadat membuat produk-produk dari Riau lebih mudah diterima oleh negara tetangga. Selain itu kekhasan kewirausahaan lokal adalah kemampuan wirausaha dalam menciptakan peluang usaha dari potensi yang terdapat lingkungannya, dengan menggunakan daya kreasi dan berinovasi serta kemampuan untuk memanfaatkan potensi pasar dengan baik.

\section{PEMBAHASAN}

\section{Analisis Pengembangan Wirausaha Lokal Kota Pekanbaru}

Berdasarkan analisis sebelumnya yang menunjukkan bahwa sektor yang mempunyai daya saing tinggi di Kota Pekanbaru adalah sektor listrik, gas, dan air minum, sektor bangunan, sektor perdagangan, hotel dan restoran, sektor pengangkutan dan komunikasi, sektor keuangan, persewaan dan jasa perusahaan, serta sektor jasa-jasa, maka selanjutnya dilakukan identifikasi dan penentuan komoditi/produk/jenis usaha unggulan berdasarkan pendapat responden/nara sumber.

Berdasarkan pendapat responden sebagai pelaku usaha dan dikombinasi dengan basis daerah diperoleh gambaran sebagaimana tertuang dalam Tabel 5.15. jenis usaha unggulan menurut sektor usahanya. Untuk sektor Perdagangan, Hotel dan Restoran jenis usaha yang potensial adalah jenis usaha Rumah Makan /Kedai Kopi, Kedai Harian/ Kelontong, Perdagangan Pakaian, Kios Pulsa/ HP, Perdagangan Perabot/Alat Rumah Tangga, Perdagangan Hasil pertanian, dan Perdagangan ATK.
Sektor Pengangkutan dan Komunikasi jenis usaha potensial adalah jenis usaha Angkutan Barang, AKDP, dan Angkutan Khusus. Sektor usaha Jasa-Jasa jenis usaha potensial adalah jasa perbengkelan, jasa reklame, jasa reparasi, jasa pendidikan, jasa kesehatan dan jasa percetakan.

Dari sekian banyak peluang usaha yang bisa dijalankan, pada kesempatan ini dapat disimpulkan jenis usaha yang memiliki prospek secara ekonomi dan dapat dikembangkan oleh wirausaha lokal adalah sebagai berikut:

1. Bisnis Properti. Prospek bisnis property masih sangat menjanjikan hal ini dipengaruhi oleh kondisi perekonomian yang semakin membaik dan tingginya tingkat kebutuhan hunian yang semakin besar. Bahkan diperkirakan pertumbuhan bisnis perumahan di tengah kota akan tumbuh hingga $12 \%$, bisnis ruko, rukan, dan apartemen di lokasi strategis berkembang sampai 10$15 \%$, sedangkan bisnis perkantoran dan hotel akan mengalami pertumbuhan sekitar $10-12 \%$, sementara bisnis mall dan trade center meningkat $5-7 \%$ (sumber, olahan)

2. Bisnis Makanan dan Minuman. Beberapa tahun belakangan ini perkembangan bisnis makanan memang mengalami peningkatan yang cukup pesat, hal ini dibuktikan dengan menjamurnya bisnis restoran, kedai kuliner, hingga berbagai macam penawaran bisnis franchise makanan yang semakin hari semakin meramaikan persaingan pasar di berbagai pelosok daerah. Kondisi seperti ini diperkirakan akan semakin cerah di tahun mendatang, sehingga peluang sukses bisnis makanan dan minuman semakin terbuka lebar.

3. Bisnis Perdagangan Energi. Meningkatnya perekonomian masyarakat menjadikan kebutuhan BBM dan Energi semakin hari semakin diburu konsumen. Tidaklah heran bila sekarang ini peluang bisnis pertambangan dan energi semakin

p.ISSN: $2407-800 X \quad$ e.ISSN: 2541-4356 
menjanjikan untung besar bagi pelakunya. Misalnya saja seperti menjalankan bisnis agen gas elpiji maupun mendirikan SPBU (Stasiun Pengisi Bahan Bakar Umum) untuk memenuhi kebutuhan BBM masyarakat yang mengalami peningkatan tajam.

4. Bisnis Jasa. Selain memenuhi kebutuhan aneka macam produk pokok yang dibutuhkan masyarakat, bisnis jasa juga menjadi alternatif tepat bagi para pemula yang ingin menekuni sebuah usaha. Di tahun yang serba modern seperti sekarang ini, masyarakat cenderung menginginkan segala hal bisa dikerjakan secara praktis, sehingga mereka memilih menggunakan pelayanan jasa untuk mempermudah rutinitas mereka setiap harinya. Contohnya saja seperti bisnis jasa laundry, asuransi, bisnis salon kecantikan dan spa, jasa reparasi barang elektronik, bisnis bengkel motor maupun mobil, dan lain sebagainya.

5. Bisnis Online. Era digital yang semakin berkembang mengantarkan peluang bisnis online di wilayah perkotaan merupakan kebutuhan bagi masyarakat kota Metropolitan. Bahkan sekarang ini hampir setiap orang sudah bisa mengakses internet dengan mudah, sehingga segala macam transaksi via online semakin diminati para konsumen. Seperti misalnya membeli aneka macam produk melalui toko online, memanfaatkan jasa pembayaran online (listrik, telepon, dll), mencari informasi penting melalui media online, dan masih banyak lagi kebutuhan lainnya yang bisa dipenuhi masyarakat melalui bantuan internet. diharapkan para pengusaha maupun para pemula yang tertarik menekuni dunia usaha bisa lebih termotivasi untuk mengembangkan usahanya dan lebih jeli dalam memilih prospek usaha. Ciptakan peluang bisnis baru yang lebih besar dan dapatkan keuntungan yang lebih menjanjikan. Kesuksesan para wirausaha akan mampu berkontribusi dalam mengurangi angka kemiskinan di Provinsi Riau

\section{Analisis Pengembangan Wirausaha Lokal Kota Dumai}

Berdasarkan analisis LQ sebelumnya menunjukkan bahwa sektor yang mempunyai daya saing tinggi di Kota Dumai adalah sektor listrik, gas, dan air bersih, sektor bangunan, sektor perdagangan, hotel dan restoran, sektor angkutan/komunikasi, sektor keuangan, persewaan/jasa perusahaan, dan sektor jasajasa. Selanjutnya dilakukan identifikasi dan penentuan komoditi/produk/jenis usaha unggulan berdasarkan pendapat responden/nara sumber.

Berdasarkan pendapat responden sebagai pelaku usaha dan dikombinasi dengan basis daerah diperoleh gambaran sebagaimana tertuang dalam Tabel 5.16. jenis usaha unggulan menurut sektor usahanya. Untuk sektor Perdagangan, Hotel dan Restoran jenis usaha yang potensial adalah jenis usaha Rumah Makan /Kedai Kopi, Kedai Harian/ Kelontong, Perdagangan Pakaian, Kios Pulsa/ HP, Perdagangan Perabot/Alat Rumah Tangga, Perdagangan Hasil pertanian, dan Perdagangan ATK. Sektor industry pengolahan jenis usaha potensial adalah jenis usaha industry pengolahan $\mathrm{CPO} /$ turunannya, industry keripik ubi, industry batu bata, industry tahu/tempe, industry tenun, industry kue dan roti.

Berdasarkan 2 sektor utama tersebut maka berikut ini adalah jenis kewirausahaan yang dapat dikembangkan di Kota Dumai sebagai berikut :

1. Produk turunan kelapa sawit, seperti minyak gorang, minyak salad, biodiesel, sabun cuci, es krim, margarin dan lain-lain.

2. Kerupuk ubi. Penyebaran ubi kayu hampir ada disetiap kabupaten di Provinsi Riau dan tidak memerlukan perawatan yang rumit menyebabkan jumlah produksi ubi sangat besar dan hampir disetiap kabupaten memiliki industry rumah tangga yang memproduksi kerupuk ubi. 
3. Usaha roti dan kue. Usaha roti dan kue merupakan produk budaya turun temurun yang selalu dijumpai disetiap acara budaya di provinsi Riau. Bahan baku yang mudah dijumpai dan permintaan yang berkesinambungan merupakan kekuatan industry ini. Kemasan yang menarik dan higienis, desain roti dan kue yang menarik dan variasi rasa merupakan factor penting bagi perkembangan usaha ini.

4. Industri Olahan Makanan. Salah satu usaha potensial yang dapat dikembangkan adalah jenis usaha agroekonomi. Komoditi olahan jamur tiram menjadi salah satu produk unggulan yang dapat dikembangkan namun masih memerlukan dukungan dalam ha pengembangannya dari pemerintah. Selain jamur tiram jenis komoditi nenas juga menjadi unggulan terutama di Kecamatan Bukit Kapur

5. Industri Batu Bata. Kota Dumai yang terus tumbuh dan berkenbang sebagai kota industri dan perdagangan memicu tingkat pembangunan konstruksi juga tinggi. Dalam kegiatan pembangunan diperlukan berbagai material bangunan seperti Batu Bata. Dumai memiliki kekhasan usaha Batu Bata. Sentra Batu Bata Kota Dumai berada pada Kecamatan Sungai Sembilan dan Kecamatan Dumai Barat.

\section{Analisis Pengembangan Wirausaha Lokal Kabupaten Kampar}

Berdasarkan analisis

menunjukkan bahwa sektor yang mempunyai daya saing tinggi di Kabupaten Kampar adalah sektor pertambangan dan penggalian, serta sektor pertanian, maka selanjutnya dilakukan identifikasi dan penentuan komoditi/jenis usaha unggulan berdasarkan pendapat responden/nara sumber.

Berdasarkan pendapat responden sebagai pelaku usaha dan dikombinasi dengan basis daerah diperoleh gambaran sebagaimana tertuang dalam Tabel 5.17. jenis usaha unggulan menurut sektor usahanya. Untuk sektor pertanian jenis usaha yang potensial adalah jenis usaha pertanian tanaman pangan, perkebunan dan peternakan. Sektor industry pengolahan jenis usaha potensial adalah jenis usaha industry pengolahan $\mathrm{CPO} /$ turunannya, industry keripik nenas, industry pandai besi, industry tahu/tempe, industry pengolahan ikan/ikan salai patin dan, industry kue dan roti.

Berdasarkan 2 sektor utama tersebut maka berikut ini adalah jenis kewirausahaan yang dapat dikembangkan di Kabupaten Kampar sebagai berikut :

1. Salai ikan patin, nugget ikan patin, abon ikan patin, bakso patin, ikan asin patin, kerupuk ikan dan produk turunan ikan lainnya. Produk turunan patin saat ini tengah dikembangkan di Desa Koto Mesjid Kec XIII Koto Kampar Kabupaten Kampar, pengembangan produk turunan patin ini merupakan antisipasi terhadap kejenuhan pasar ikan patin, kejatuhan harga ikan patin segar disebabkan berlebihnya penawaran ikan patin segar di pasar sehingga ketika menjual ikan patin segar tidak lagi menjanjikan keuntungan yang baik mereka sudah siap beralih memproduksi dan menjual produk turunannya. Saat ini pengembangan produk turunan ikan patin ini masih tahap penciptaan dan pengembangan produk sembari mencari peluang pasar. Selain di Kabupaten Kampar yang telah di tetapkan sebagai Daerah Minapolitan Sentral Produksi Ikan Patin di Indonesia, kabupaten lain seperti Kabupaten Kuantan Singingi yang saat ini memiliki 1435 Rumah Tangga Perikanan (RTP) budidaya kolam dengan luas kolam 204,18 ha memiliki prospek untuk mengembangkan produk turunan ikan. Kabupaten Pelalawan yang memiliki potensi 189,31 ha keramba

p.ISSN: $2407-800 X \quad$ e.ISSN: 2541-4356 
sungai dan 29,5 ha keramba danau juga memiliki peluang pengembangan produk turunan ikan. Kabupaten Indragiri Hulu memiliki potensi juga untuk pengembangan produk turunan ikan, meskipun produksi ikan kolam dari kabupaten ini tidaklah terlalu besar ( 325 ton pada tahun 2009) namun kesejahteraan RTP dapat ditingkatkan melalui nilai tambah dari produk turunannya, ikan Nila yang merupakan ikan kolam terbesar yang di hasilkan Kabupaten Indragiri Hulu bisa dipertimbangkan untuk dikembangkan produk turunannya. Di Kabupaten Rokan Hulu ikan yang dihasilkan telah mendapatkan pertambahan nilai melalui proses penggaraman dan pengasapan, pada tahun 2010 telah dihasilkan 3943,16 ton ikan segar, 84,1 ton penggaraman ikan dan 365,38 ton pengasapan ikan. Usaha abon ikan juga ditemukan di Kabupaten Rokan Hulu tepatnya di Desa Sei Kuning Kecamatan Kepenuhan , bahan baku yang digunakan adalah ikan lomak, ikan gabus, ikan nila dan ikan bersisik lainnya, usaha ini masih terkendala di permasalahan pemasaran dan modal, peralatan yang belum memadai dan jauhnya akses dari pabrik ke ibukota kabupaten.

2. Produk turunan kelapa sawit, seperti minyak goreng, minyak salad, sabun cuci, es krim, margarin dan lain-lain. Hampir semua kawasan di provinsi Riau dapat menghasilkan produk turunan kelapa sawit terutama kawasan daratan yang memiliki produksi kelapa sawit yang sangat besar seperti Kabupaten Kampar dengan pada tahun 2010 luas lahan 359.807 ha dengan produksi 5.353.628 ton, Kabupaten Rokan Hulu pada tahun 2010 memiliki luas lahan sawit 207.804,18 dengan produksi sawit sebanyak 2.216.110,80 ton, Kabupaten Kuantan Singingi pada tahun 2011 memiliki luas lahan perkebunan sawit sebesar $120.578,59$ ha dengan total produksi sebesar 325.379,93 ton dan Kabupaten Pelalawan pada tahun 2011 memiliki 334.603,37 ha lahan kelapa sawit dengan produksi sebesar 1.525.336,45 ton.

3. Produk turunan dari buah-buahan tropis. Produk turunan buah-buahan tropis seperti keripik yang berasal dari buah-buahan contohnya keripik nangka, keripik nenas; selai, dodol buah, sirup, tepung sari, buahbuahan kaleng. Semua kabupaten di Provinsi ini memproduksi buahbuahan tropis. Beragamnya produk turunan buah-buahan ini memberikan banyak alternative pengembangan produk. Untuk saat ini yang sering dijumpai di pasaran adalah produk turunan nenas, nangka dan durian. Desa Kualu Nenas Kecamatan Tambang terdapat produsen keripik nangka dan nenas dengan kapasitas produksi keripik nangka $2000 \mathrm{~kg} /$ tahun dan keripik nenas $2000 \mathrm{~kg} /$ tahun.

4. Pandai besi. Usaha pandai besi sangat sesuai dikembangkan pada daerah yang memiliki perkebunan kelapa sawit. Produk yang dihasilkan adalah: parang, dodos, kampak, babat, dan agrek. Kabupaten Kampar yang memiliki luas lahan kelapa sawit terluas memiliki Sentra Pandai Besi Rumbio Jaya yang berlokasi di Desa Teratak Kecamatan Rumbio Jaya. Sentra pandai besi ini adalah binaan Disperindag Kabupaten Kampar dan menaungi lebih kurang 80 orang pengrajin. Rendahnya kualitas bahan baku dan sulitnya permodalan menjadi hambatan perkembangan serta persaingan dengan produk Malaysia yang lebih berkualitas dan murah menjadi ancaman bagi usaha ini. Di Kabupaten Rokan Hulu tepatnya di Desa Tambusai Barat 
Kecamatan Tambusai juga terdapat beberap kelompok pengrajin namun jumlahnya tidak sebanyak di kabupaten Kampar.

5. Kue Tradisional. Salah satu kue tradisional Kabupaten Kampar adalah jenis lepat Bugis. Jenis olahan rumah tangga ini cukup banyak diminati dan dapat dikembangkan. Sentra usaha lepat bugis ini berada di Kecamatan Tambang, bahkan saat ini usaha ini telah mampu merambah Kota Pekanbaru.

\section{Analisis Pengembangan Wirausaha Lokal Kabupaten Rokan Hulu}

Berdasarkan analisis LQ sebelumnya menunjukkan bahwa sektor yang mempunyai daya saing tinggi di Kabupaten Rokan Hulu adalah sektor pertanian dan sektor industri pengolahan. Selanjutnya dilakukan identifikasi dan penentuan komoditi/produk/jenis usaha unggulan berdasarkan pendapat responden/nara.

Berdasarkan pendapat responden sebagai pelaku usaha dan dikombinasi dengan basis daerah diperoleh gambaran sebagaimana tertuang dalam Tabel 5.18. jenis usaha unggulan menurut sektor usahanya. Untuk sektor pertanian jenis usaha yang potensial adalah jenis usaha pertanian tanaman pangan, perkebunan dan peternakan. Sektor industry pengolahan jenis usaha potensial adalah jenis usaha industry pengolahan $\mathrm{CPO} /$ turunannya, industry keripik ubi, industry pandai besi, industry gerabah, industry abon ikan dan, industry kue dan roti dan lainnya.

Berdasarkan 2 sektor utama tersebut maka berikut ini adalah jenis kewirausahaan yang dapat dikembangkan di Kabupaten Rokan Hulu sebagai berikut :

1. Produk turunan kelapa sawit, seperti minyak gorang, minyak salad, sabun cuci, es krim, margarin dan lain-lain. Hampir semua kawasan di Provinsi Riau dapat menghasilkan produk turunan kelapa sawit terutama kawasan daratan untuk Kabupaten Rokan Hulu pada tahun 2010 memiliki luas lahan sawit
207.804,18 dengan produksi sawit sebanyak 2.216.110,80 ton,

2. Kerupuk ubi. Penyebaran ubi kayu hampir ada disetiap kabupaten di Provinsi Riau dan tidak memerlukan perawatan yang rumit menyebabkan jumlah produksi ubi sangat besar dan hampir disetiap kabupaten memiliki industry rumah tangga yang memproduksi kerupuk ubi.

3. Kerajinan gerabah. Bahan baku gerabah berupa tanah liat dan pasir mudah sekali di jumpai di kabupaten-kabupaten di Provinsi Riau. Usaha kerajinan gerabah di Kabupaten Rokan hulu tepatnya di Desa Rambah Utama Kecamatan Rambah Samo berproduksi menggunakan alat-alat tradisional dan menghasilkan lebih kurang 20 buah gerabah setiap harinya dengan harga jual Rp 5.000 / buah hingga Rp 30.000 / buah, pengetahuan mengenai desain produk sangat diperlukan untuk bersaing dengan produk gerabah dari daerah lain, pengetahuan marketing dan perkenalan kepada pasar yang lebih luas diperlukan untuk perkembangan usaha ini.

4. Pandai besi. Usaha pandai besi sangat sesuai dikembangkan pada daerah yang memiliki perkebunan kelapa sawit. Produk yang dihasilkan adalah: parang, dodos, kampak, babat, dan agrek. Rendahnya kualitas bahan baku dan sulitnya permodalan menjadi hambatan perkembangan serta persaingan dengan produk Malaysia yang lebih berkualitas dan murah menjadi ancaman bagi usaha ini. Di Kabupaten Rokan Hulu tepatnya di Desa Tambusai Barat Kecamatan Tambusai juga terdapat beberap kelompok pengrajin namun jumlahnya masih sedikit.

5. Kerajinan anyaman dari bahan baku pandan dan lidi sawit. Pandan sangat mudah karena dapat dengan mudah hidup di iklim tropis sedangkan lidi sawit diperoleh dari pelepah sawit. Pengetahuan akan desain dan saluran distribusi akan sangat membantu para 
pengrajin anyaman ini. Usaha ini dapat berkembang baik pada daerah perkebunan sawit.

6. Bordir. Usaha bordir merupakan usaha turun temurun yang terus diupayakan kelestariannya, kurangnya minat anak muda dalam menekuni usaha border ini merupakan kendala dalam pelestarian dan pengembangan usaha ini. Bantuan mesin produksi dan peremajaan mesin mutlak diperlukan. Pengetahuan akan desain dan system pemasaran pun mesti menjadi perhatian.

7. Sari jahe dan tinting jahe. Industry jahe mulai berkembang di Kabupaten Rokan Hulu, dengan system produksi yang masih tradisional saat ini mampu menghasilkan pesanan sebanyak $80-100$ bungkus per hari. Permasalahan yang dihadapi wirausaha industry jahe ini adalah produksi belum bersifat massal karena berproduksi sesuai pesanan, perlu peningkatan mutu dan kemasan.

8. Usaha roti dan kue. Usaha roti dan kue merupakan produk budaya turun temurun yang selalu dijumpai disetiap acara budaya di provinsi Riau. Bahan baku yang mudah dijumpai dan permintaan yang berkesinambungan merupakan kekuatan industry ini. Kemasan yang menarik dan higienis, desain roti dan kue yang menarik dan variasi rasa merupakan factor penting bagi perkembangan usaha ini.

\section{Analisis Pengembangan Wirausaha Lokal Kabupaten Rokan Hilir}

Berdasarkan analisis LQ sebelumnya menunjukkan bahwa sektor yang mempunyai daya saing tinggi di Kabupaten Rokan Hilir adalah sektor pertanian dan sektor perdagangan, hotel dan restoran. Selanjutnya dilakukan identifikasi dan penentuan komoditi/produk/jenis usaha unggulan berdasarkan pendapat responden/nara sumber.

Berdasarkan pendapat responden sebagai pelaku usaha dan dikombinasi dengan basis daerah diperoleh gambaran sebagaimana tertuang dalam Tabel 5.19. jenis usaha unggulan menurut sektor usahanya. Untuk sektor pertanian jenis usaha yang potensial adalah jenis usaha pertanian buahan, dan perkebunan. Sektor perdagangan jenis usaha yang potensial adalah jenis rumah makan/kedai kopi, kedai harian, bahan bangunan, keperluan pertanian dan lainnya. Untuk industry pengolahan jenis usaha potensial adalah jenis usaha industry pengolahan $\mathrm{CPO} /$ turunannya, industry keripik nenas, industry pengolahan ikan dan industry kue kering.

Berdasarkan 3 sektor utama tersebut maka berikut ini adalah jenis kewirausahaan yang dapat dikembangkan di Kabupaten Rokan Hilir sebagai berikut :

1. Produk turunan kelapa sawit, seperti minyak gorang, minyak salad, sabun cuci, es krim, margarin dan lain-lain. Hampir semua kawasan di Provinsi Riau dapat menghasilkan produk turunan kelapa sawit.

2. Usaha makanan olahan /kue kering. Usaha makanan dan kue kering merupakan produk budaya turun temurun . Bahan baku yang mudah dijumpai dan permintaan yang berkesinambungan merupakan kekuatan industry ini. Kemasan yang menarik dan higienis, desain makanan dan kue yang menarik dan variasi rasa merupakan factor penting bagi perkembangan usaha ini. Untuk usaha makanan yang menjadi unggulan di Kabupaten Rokan Hilir adalah makanan olahan kacang dalam bentuk kacang pukul. Selain usaha kacang pukul jenis usaha lainnya adalah pembuatan kecap, bahkan untuk kecap jangkauan pemasarannya produknya sudah ekspor.

3. Usaha Pengolahan Hasil Perikanan. Kabupaten Rokan Hilir memiliki potensi perikanan yang cukup besar terutama untuk perikanan tangkap.

4. Pertanian buah nenas dan produk olahannya. Potensi pertanian buah

p.ISSN: $2407-800 X \quad$ e.ISSN: $2541-4356$ 
nenas banyak terdapat di Kabupaten Rokan Hilir terutama pada Kecamatan Tanah Putih dan Tjg Melawan. Potensi nenas diperkirakan hampir seluas 600 ha. Dari jumlah tersebut dengan tersediaan lahan masih dapat dikembangkan. Selain pengembangan pertaniannya dapat pula dilakukan pengembangan produk olahan dari nenas, saat ini jenis olahan yang telah dilakukan adalah membuat keripik nenas dan selai nenas.

5. Industri Pembuatan Kapal. Geografis wilayah Kabupaten Rokan Hilir merupakan wilayah pesisir yang juga terdiri dari pulau-pulau, sehingga kebutuhan akan sarana transportasi laut menjadi kebutuhan pokok bagi sebagian masyarakatnya. Dengan kondisi alam ini kebutuhan akan kapal menjadi sangat diperlukan selain untuk kegiatan transportasi juga merupakan sarana pokok untuk kegiatan usaha perikanan terutama nelayan.

\section{Analisis Pengembangan Wirausaha Lokal Kabupaten Indragiri Hilir}

Berdasarkan analisis LQ sebelumnya menunjukkan bahwa sektor yang mempunyai daya saing tinggi di Kabupaten Indragiri Hilir adalah sektor pertanian. Selanjutnya dilakukan identifikasi dan penentuan komoditi/produk/jenis usaha unggulan berdasarkan pendapat responden/nara sumber.

Berdasarkan pendapat responden sebagai pelaku usaha dan dikombinasi dengan basis daerah diperoleh gambaran sebagaimana tertuang dalam Tabel 5.20. jenis usaha unggulan menurut sektor usahanya. Untuk sektor pertanian jenis usaha yang potensial adalah jenis usaha pertanian tanaman pangan, perkebunan dan perikanan. Untuk industry pengolahan jenis usaha potensial adalah jenis usaha industry pengolahan $\mathrm{CPO} /$ turunannya, industry pengolahan kelapa dan turunannya, industry sagu, industry pengolahan nenas, industry pengolahan ikan, industry kue kering dan industry anyaman.

Berdasarkan 2 sektor utama tersebut maka berikut ini adalah jenis kewirausahaan yang dapat dikembangkan di Kabupaten Indragiri Hilir sebagai berikut :

1. Produk turunan kelapa sawit, seperti minyak goreng, minyak salad, , sabun cuci, es krim, margarin dan lain-lain. Hampir semua kawasan di Provinsi Riau dapat menghasilkan produk turunan kelapa sawit.

2. Usaha Olahan Kelapa; Keripik Kelapa: Contoh. "Keripik kelapa dengan merek Danielle, produk milik seorang WNI yang telah lama bermukim di Boston, Amerika Serikat (AS), memenangkan penghargaan Sofi Awards 2012. Anugerah itu diberikan di pameran makanan terkemuka AS, Fancy Food Show. "Penghargaan ini diberikan di Fancy Food Show, pameran makanan tahunan terbesar di AS, kepada produk makanan dan minuman yang paling menonjol dan inovatif,". Briket sabut kelapa (cocopeat) sebagai media bitumman dalam reklamasi lahan tambang. Pertambangan tidak hanya membinasakan keanekaragaman tanaman di hutan, namun juga mengelupas tanah sampai miskin hara. Untuk menumbuhkan biji-biji tanaman di hutan rusak, dapat dilakukan dengan menggunakan Bitumman yang merupakan biji tumbuh mandiri hasil simbiosis mikoriza abuskular dan bakteri rizosfer. Mikoriza abuskular adalah jamur yang banyak terdapat di akar pohon pinus dengan ikutannya bakteri rizosfer. "Tanpa mikoriza, akar yang mulai tumbuh dari bijibijian akan sulit mengambil nitrogen dan fosfor untuk 
pertumbuhan,". Mikoriza memiliki keunikan, yaitu akan tumbuh dengan baik justru di lahan yang kurang atau sama sekali tidak subur, misalnya lahan-lahan bekas tambang. Ketiadaan hara memicu mikoriza tumbuh optimal untuk mengikat nitrogen dan fosfor sebanyak-banyaknya dari atmosfer. Sistem pertahanan hidup mikoriza seperti itu dimanfaatkan untuk memodifikasi bibit tanaman revegetasi yang bertujuan menghutankan kembali lahan rusak. Bitumman telah dicoba dirakit dari beberapa biji tanaman, di antaranya biji akasia dan albizia, yang pada usia 18 bulan mampu tumbuh di atas rata-rata.

3. Pertanian buah nenas dan produk olahannya. Potensi pertanian buah nenas banyak terdapat di Kabupaten Indragiri Hilir. Dari jumlah tersebut dengan tersediaan lahan masih dapat dikembangkan. Selain pengembangan pertaniannya dapat pula dilakukan pengembangan produk olahan dari nenas, saat ini jenis olahan yang telah dilakukan adalah membuat keripik nenas dan selai nenas.

6. Usaha makanan olahan /kue kering. Usaha makanan dan kue kering merupakan produk budaya turun temurun. Bahan baku yang mudah dijumpai dan permintaan yang berkesinambungan merupakan kekuatan industry ini. Kemasan yang menarik dan higienis, desain makanan dan kue yang menarik dan variasi rasa merupakan factor penting bagi perkembangan usaha ini.

\section{SIMPULAN}

Dari uraian mengenai pengembangan wirausaha local di Propinsi Riau, maka dapat ditarik kesimpulan bahwa pengembangan wirausaha yang berbasis pengembangan ekonomi lokal diuraikan untuk 6 kabupaten/kota yang menjadi lokasi penelitian ini. Penentuan komoditi unggulan ditentukan dengan kriteria yang telah ditetapkan sebelumnya, dan penentuan kriteria tersebut dilandasi oleh tujuan yang ingin dicapai dalam pengembangan wirausaha lokal. Untuk memperoleh keseragaman dan konsistensi dalam proses penetapan komoditi unggulan, maka setiap kriteria yang digunakan pada semua kabupaten/kota adalah sama.

Salah satu dari sifat kewirausahaan adalah bertindak berdasarkan peluang bisnis, peluang bisnis bisa diperoleh dari mencermati dan menganalisa tiga potensi berikut yaitu :

1. Ketersediaan SDA. Bahan baku atau sumber daya alam bisa langsung diperoleh dari alam, dari budi daya atau didatangkan dari daerah lain. Pemilihan dari ketiga alternative sumber bahan baku ini adalah semata-mata factor efisiensi

2. Ketersediaan SDM. Tenaga kerja terampil dan tidak terampil memiliki potensi untuk maju

3. Potensi Pasar. Potensi pasar atau peluang permintaan komoditas bersumber dari dalam dan luar negeri, kedekatan budaya, selera dan adat istiadat membuat produkproduk dari Riau lebih mudah diterima oleh negara tetangga. Selain itu kekhasan kewirausahaan lokal adalah kemampuan wirausaha dalam menciptakan peluang usaha dari potensi yang terdapat lingkungannya, dengan menggunakan daya kreasi dan berinovasi serta kemampuan untuk memanfaatkan potensi pasar dengan baik. 


\section{DAFTAR RUJUKAN}

AmirullahdanHardjanto.

PengantarBisnis.

2005 .

07. Mari membangun Usaha Mandiri, PedomanPraktisbagi UKM.

GrahaIlmu. Yogyakarta.

C.K. Prahalad, The Fortune at The Bottom of the Pyramid. Wharton School Publishing, 2005.

Daniel Jennings, Multiple Perspectives of Entrepreneurship: Text, Readings, and Cases.South-Western Publishishing Co, 1994.

Jeffry Timmons and Stephen Spinelli. New Venture Creation, Entrepreneurship for the 21st Century.7th ed., McGraw-Hill Education, International, 2007.

Kasmir. 2006. Kewirausahaan. PT RajagrafindoPersada. Jakarta.

Peter Drucker, Innovation and Entrepreneurship: Practice and Principles.William Heinemann Ltd, 1985. www.3babson.edu

Philip Wickham. Strategic Entrepreneurship.3rd ed., Pearson Education Limited, 2004.Ibid hal 110.

Robin Lowe and Sue Marriot, Enterprise: Entrepreneurship and Innovation, Concepts, Contexts, and Commercialization, ButterworthHeinemann, 2006, hal $18-20$ dan 65 -84 .

Samsir. 2005. Pengaruh Jiwa Kewirausahaan Terhadap Keberhasilan Usaha Pada Industri Kecil Makanan di Kota Pekanbaru. Universitas Padjajaran. Bandung.
Suryana dan Bayu. 2001. Kewirausahaan, PendekatanKarakteristikWirausahaa nSukses. KENCANA Prenada Media Group. Jakarta.

Timmons and Spinelli. 2004. New Venture Creation, Entrepreneurship for the 21 st Century. Andy. Yogyakarta.

Tunggal Amijaya W. 2004. ManajemenKewirausahaan. Havarindo. Jakarta

Vita Sari. 2001. Policy Recommendation for SME Promotion in the Republic of Indonesia. Japan International Cooperation Agency. Japan

Zimmerer. Scarborough. 2008. Essential of Entrepreneurship and Small Bussiness Management. Pearson Education. New Jersey. 